\title{
Academic Procrastination Behaviors of Preservice Teachers in Turkish Context
}

\author{
Öznur Ataş Akdemir ${ }^{1, *}$ \\ ${ }^{1}$ Faculty of Education, Firat University, Elazı̆̆g, Turkey \\ *Correspondence: Faculty of Education, Frrat University, Elazığ, Turkey. Tel: 90-543-528-8865. E-mail: \\ oznuratasakdemir@gmail.com
}

Received: January 31, 2019

Accepted: March 1, 2019 Online Published: March 12, 2019

doi:10.5430/wje.v9n2p13

URL: https://doi.org/10.5430/wje.v9n2p13

\begin{abstract}
Current study aims at investigating the academic procrastination behaviors of preservice teachers in terms of different variables. The research is conducted with 211 undergraduate students studying at the faculty of education at a public university in Turkey. The study is designed in descriptive survey model in which the data is collected with the instrument of Academic Procrastination Scale. Standard deviation, arithmetic mean, frequency, percentage, $t$ test, one-way analysis of variance (ANOVA) and Scheffe and Tukey test are used as data analysis procedures. The results showed that preservice teachers do not mostly exhibit behaviors of academic procrastination, irresponsibility, quality of perceived academic task, negative perceptions regarding instructors and academic perfectionism. Additionally, there are some differences between preservice teachers' behaviors of academic procrastination in terms of gender, departments and class level. The findings are discussed in the light of relevant literature and implications for theory and practice have been presented along with concluding remarks.
\end{abstract}

Keywords: preservice teachers, academic procrastination, gender, department, class level

\section{Introduction}

If assignments and studies which should be carried out or which are planned to be carried out in a specific time interval are not completed on time, it creates serious problems for students, instructors, and academicians. The term academic procrastination is used to describe this phenomenon. The relevant literature gives several definitions of the term. Kağan (2009) defines the academic procrastination behavior as the problems with which students face when they try to prepare their studies related to exams and projects on time. In another definition which focuses on the underlying reasons of academic procrastination behavior, Senecal, Julien and Gay (2003) mention the tendency to delay starting and carrying on academic assignments because of illogical reasons. Balkıs (2007) states that academic procrastination behavior, which is described as a negative and widespread feature for students or academics, is the tendency to delay or postpone carrying out an assignment or a duty in a specific time interval. Academic procrastination behavior causes anxiety inevitably. Researchers who point out this fact define academic procrastination behavior as the situation in which someone cannot start to work which should be done until he experiences anxiety to a disturbing level (Rothblum, Solomon \& Murakabi, 1986; Senecal, Koestner \& Vallerand, 1995). Research findings show that academic procrastination behavior is quite common among students from various levels or school types. It is reported that $90 \%$ of students procrastinate their academic works at least once, while $50 \%$ of them do this often, and 35\% of them do sometimes. (Hill, Hill, Chabot \& Barral, 1978; Klassen, Krawchuck \& Rajani, 2008; Solomon \& Rothblum, 1984). Steel (2007) states that 95\% of students in the US engage in procrastination. This rate is estimated as being nearly $50 \%$ with students in Turkey (Uzun Özer, Demir \& Ferrari, 2009). According to Klassen and Kuzucu (2009), more than $80 \%$ of Turkish students procrastinate their academic works at least once a day. Though there are no accurate numbers for procrastination levels among Turkish students, abovementioned figures point a high level of procrastination.

The reasons for academic procrastinate behavior have been reported as :

- Having a sense of responsibility at low level (Bacanlı, İlhan \& Arslan, 2009)

- Having poor time management skills (Balkıs, 2007; Balkıs, Duru, Buluş \& Duru, 2006) 
- Fear of failure (Uzun-Özer, 2005)

- Perfectionism (Sarığlu, 2011; Solomon \& Rothblum, 1984)

- Being unable to concentrate on tasks (Balk1s, 2007)

- Setting unrealistic targets (Balkıs, 2007).

Balkıs (2007) defines academic procrastination behavior and states that academic procrastination behavior has five sub-dimensions. These can be classified as general procrastination, academic procrastination, decision-making procrastination, neurotic procrastination, and nonfunctional procrastination. On the other hand, Kağan (2009) divides procrastination into two sub-dimensions which are chronic procrastination and situational procrastination; and it is claimed that academic procrastination should be classified under situational procrastination.

According to the literature review, academic procrastination phenomenon is investigated in terms of many different notions. As Kağan (2009) states, there is a positive correlation between procrastination and anxiety; and when the task which causes anxiety is procrastinated, the feeling of anxiety disappears for a while. This status is temporary and as a result of procrastination, anxiety comes back with a higher level. Also, Lekich (2006) highlights the relationship between motivation and procrastination behavior. According to Lekich, there is a negative correlation between procrastination behavior and internal motivation while there is a positive correlation between procrastination behavior and external motivation. Çakıcı (2003) points out the relationship between procrastination and self-esteem. According to this relationship, low self-esteem increases the rate of procrastination behavior. Uzun-Özer (2005) mentions the relationship between gender and academic procrastination behavior and says that males are more inclined to procrastinate their academic tasks. Balkıs and Duru (2007) conclude that there is a negative correlation between academic success and academic procrastination behavior. Additionally, the relationship between academic procrastination behavior and emotional intelligence is investigated and it is claimed that overcoming the stress which is one of the sub dimensions of emotional intelligence is related to academic procrastination behavior (Deniz, Traş \& Aydoğan, 2007). Ekşi and Dilmaç (2010) examine academic procrastination behavior in terms of trait-anxiety and they reveal that trait-anxiety significantly predict academic procrastination behavior. Saddler and Sacks (1993) state that procrastination is, along with perfectionism, one of the reasons for depression.

Preservice teachers who engage in academic procrastination behavior an undesirable behavior can cause negative results in terms of education. Therefore, some studies can be conducted to prevent and decrease academic procrastination behavior. In this regard, the aim of the present study is to determine academic procrastination behaviors of preservice teachers and examining these behaviors in terms of different variables. This research seeks to address the following questions:

a. How is the preservice teachers' perceptions regarding academic procrastination behaviors?

b. Do the preservice teachers' academic procrastination behaviors differentiate according to gender, department and class level?

\section{Method}

\subsection{Research Model}

Present research which aims to investigate the preservice teachers' academic procrastination behaviors, is designed as descriptive survey. By the help of survey model preservice teachers' behaviors of academic procrastination, irresponsibility, quality of perceived academic task, negative perceptions regarding instructors and academic perfectionism are determined. Also, this research intends to determine whether preservice teachers' behaviors of academic procrastination, irresponsibility, quality of perceived academic task, negative perceptions regarding instructors and academic perfectionism differ in terms of variables which are classified as gender, department and class level.

\subsection{Study Group}

211 preservice teachers studying at the faculty of education in one of Turkish universities participated in the study. Of the 211 pre-service teachers who participated in this study $114(54 \%)$ of them are female students while $97(46 \%)$ of them are male students. In terms of department, $37(17,5 \%)$ of the pre-service teachers study at Computer and Instructional Technology Teacher Education, 56 (26,5\%) of them study at Elementary Mathematics Education, 56 $(26,5 \%)$ of them study at Psychological Counseling and Guidance, $62(29,4 \%)$ of them study at Elementary Education. Additionally, $60(28,4 \%)$ of those who are participated in the present research are in 1st grade, $10(4,7 \%)$ of them are in 2nd grade, $92(43,6 \%)$ of them are in 3rd grade and $49(23,2 \%)$ of these preservice teachers are in 4 th 
grade.

\subsection{Data Collection Instrument}

In the present study "Academic Procrastination Scale" developed by Ocak and Bulut (2015) is used as data collection instrument. Academic Procrastination Scale is composed of 38 items with five Likert-type grades and four dimensions namely irresponsibility, quality of perceived academic task, negative perceptions regarding instructors and academic perfectionism. In the reliability analysis made by Ocak and Bulut (2015), it is found that the Cronbach alpha reliability coefficient of the whole scale is .92; at sub dimensions this value changes as .95 and .64 . In this research, it is found that Cronbach alpha reliability coefficient for the whole scale is .94; for sub dimensions, coefficient changes as .94 and .68. Consequently, it can be said that Academic Procrastination Scale is a reliable data collection instrument for the present study.

\subsection{Data Analysis}

Statistical analysis of the data is conducted by SPSS 24.0 packaged software. Descriptive statistical methods namely standard deviation, arithmetic mean, frequency, and percentage are conducted in data analysis step. Additionally, $\mathrm{t}$ test, one-way analysis of variance (ANOVA), Scheffe and Tukey test are employed. Significance level, also called as the critical value, or alpha level is set at the 0.05 level to test the difference between group average values.

\section{Findings}

In this section, findings that show whether preservice teachers' behaviors of academic procrastination differ according to different variables are presented.

Findings related to preservice teachers' behaviors of academic procrastination and its sub dimensions are given in the Table 1.

Table 1. Descriptive Analysis of Academic Procrastination Behavior and Its Sub-Dimensions

\begin{tabular}{lccc}
\hline \multicolumn{1}{c}{ Dimensions } & $\mathrm{N}$ & $\mathrm{M}$ & $\mathrm{Sd}$ \\
\hline Academic procrastination behavior & 211 & 2.57 & .65 \\
Irresponsibility & 211 & 2.57 & .81 \\
Quality of perceived academic task & 211 & 2.27 & .72 \\
Negative perceptions regarding instructors & 211 & 2.98 & .94 \\
Academic perfectionism & 211 & 2.77 & .82 \\
\hline
\end{tabular}

When Table 1 is examined, it is apparent that average scores of academic procrastination behaviors of the students who participated in the present study is $(\mathrm{M}=2.57)$ which is equal to "somewhat like me" in rating scales. Preservice teachers state that the academic procrastination behaviors reflect them in some degree. When the sub dimensions related to academic procrastination behaviors are investigated, it is seen that arithmetic mean of each sub dimensions are at different levels. Accordingly, preservice teachers' level of the procrastination is the highest in the dimension called as "negative perceptions regarding instructors" $(\mathrm{M}=2.98)$ while this level is lowest in the dimension "the quality of perceived academic task" ( $\mathrm{M}=2.27)$.

Findings that show whether pre-service teachers' behaviors of academic procrastination differ in terms of gender are given in the Table 2.

Table 2. T-test Results That Presents the Pre-Service Teachers' Behaviors of Academic Procrastination in terms of Gender

\begin{tabular}{|c|c|c|c|c|c|c|c|}
\hline \multirow{2}{*}{ Dimensions } & \multicolumn{2}{|c|}{ Female $\mathrm{n}=114$} & \multicolumn{2}{|c|}{ Male $n=97$} & \multirow{2}{*}{$\mathrm{t}$} & \multirow{2}{*}{$\mathrm{df}$} & \multirow{2}{*}{$\mathrm{p}$} \\
\hline & $\mathrm{M}$ & $\mathrm{Sd}$ & $\mathrm{M}$ & $\mathrm{Sd}$ & & & \\
\hline Academic procrastination beh. & 2.46 & .69 & 2.69 & .58 & 2.537 & 209 & $.012^{*}$ \\
\hline Irresponsibility & 2.47 & .84 & 2.69 & .77 & 1.928 & 209 & .055 \\
\hline Quality of perceived academic task & 2.17 & .71 & 2.38 & .71 & 2.209 & 209 & $.028 *$ \\
\hline Negative perc. regarding instructors & 2.84 & 1.05 & 3.14 & .78 & 2.308 & 209 & $.022 *$ \\
\hline Academic perfectionism & 2.68 & .81 & 2.88 & .83 & 1.729 & 209 & .085 \\
\hline
\end{tabular}

${ }^{*} \mathrm{p}<.05$ 
Table 2 presents that the results of $t$ test which is conducted to compare the difference between female preservice teachers' academic procrastination behaviors and male preservice teachers' academic procrastination behaviors show that procrastination behaviors are different for gender groups ( $\mathrm{t} 0.05: 209=2.537)$. According to this result, male preservice teachers are more likely to procrastinate their academic works when they are compared with female preservice teachers. When this is considered from the aspect of sub dimensions namely negative perceptions regarding instructors and quality of perceived academic task, male preservice teachers perform academic procrastination behavior significantly more than female preservice teachers. On the other hand, there isn't statistically significant differences between these two groups in terms of academic perfectionism and irresponsibility.

Findings that show whether preservice teachers' behaviors of academic procrastination differ in terms of department are given in the Table 3 .

Table 3. ANOVA Results That Illustrates the Preservice Teachers' Behaviors of Academic Procrastination in terms of Department

\begin{tabular}{|c|c|c|c|c|c|c|c|c|c|c|c|}
\hline Dimensions & Department & $\mathrm{n}$ & M & $\mathrm{Sd}$ & $\begin{array}{l}\text { Source of } \\
\text { Variance }\end{array}$ & $\begin{array}{l}\text { Sum of } \\
\text { Squares }\end{array}$ & $\mathrm{df}$ & $\begin{array}{l}\text { Mean } \\
\text { Square }\end{array}$ & $\mathrm{F}$ & $\mathrm{p}$ & Difference \\
\hline \multirow{4}{*}{$\begin{array}{c}\text { Academic procrastination } \\
\text { behavior }\end{array}$} & A & 37 & 2.65 & .60 & B. G. & 3.928 & 3 & 1.309 & \multirow{4}{*}{3.206} & \multirow{4}{*}{$.024 *$} & \multirow{4}{*}{$\mathrm{D}<\mathrm{C}$} \\
\hline & $\mathrm{B}$ & 56 & 2.54 & .69 & W. G. & 84.554 & 207 & .408 & & & \\
\hline & $\mathrm{C}$ & 56 & 2.74 & .49 & & & & & & & \\
\hline & $\mathrm{D}$ & 62 & 2.39 & .73 & & & & & & & \\
\hline \multirow{4}{*}{ Irresponsibility } & A & 37 & 2.63 & .77 & B. G. & 3.400 & 3 & 1.133 & \multirow{4}{*}{1.726} & \multirow{4}{*}{.163} & \multirow{4}{*}{-} \\
\hline & B & 56 & 2.58 & .86 & W. G. & 135.938 & 207 & .657 & & & \\
\hline & $\mathrm{C}$ & 56 & 2.73 & .69 & & & & & & & \\
\hline & $\mathrm{D}$ & 62 & 2.40 & .89 & & & & & & & \\
\hline \multirow{4}{*}{$\begin{array}{l}\text { Quality of perceived } \\
\text { academic task }\end{array}$} & A & 37 & 2.38 & .70 & B. G. & 5.378 & 3 & 1.793 & \multirow{4}{*}{3.610} & \multirow{4}{*}{$.014 *$} & \multirow{4}{*}{$\mathrm{D}<\mathrm{C}$} \\
\hline & B & 56 & 2.15 & .67 & W. G. & 102.786 & 207 & .497 & & & \\
\hline & $\mathrm{C}$ & 56 & 2.49 & .65 & & & & & & & \\
\hline & $\mathrm{D}$ & 62 & 2.11 & .78 & & & & & & & \\
\hline \multirow{4}{*}{$\begin{array}{l}\text { Negative perceptions } \\
\text { regarding instructors }\end{array}$} & A & 37 & 3.01 & .70 & B. G. & 12.301 & 3 & 4.100 & \multirow{4}{*}{4.849} & \multirow{4}{*}{$.003 *$} & \multirow{4}{*}{$\begin{array}{l}\mathrm{D}<\mathrm{B} \\
\mathrm{D}<\mathrm{C}\end{array}$} \\
\hline & B & 56 & 3.15 & 1.07 & W. G. & 175.047 & 207 & .846 & & & \\
\hline & $\mathrm{C}$ & 56 & 3.19 & .81 & & & & & & & \\
\hline & $\mathrm{D}$ & 62 & 2.62 & .98 & & & & & & & \\
\hline \multirow{4}{*}{ Academic perfectionism } & A & 37 & 2.99 & .88 & B. G. & 3.862 & 3 & 1.287 & \multirow{4}{*}{1.945} & \multirow{4}{*}{.123} & \multirow{4}{*}{-} \\
\hline & $\mathrm{B}$ & 56 & 2.59 & .84 & W. G. & 137.019 & 207 & .662 & & & \\
\hline & $\mathrm{C}$ & 56 & 2.85 & .76 & & & & & & & \\
\hline & $\mathrm{D}$ & 62 & 2.77 & .82 & & & & & & & \\
\hline \multicolumn{6}{|c|}{ A. Computer and Instructional Technology Teacher Education } & \multicolumn{5}{|c|}{ B. Elementary Mathematics Education } & \\
\hline \multicolumn{6}{|c|}{ C. Psychological Counseling and Guidance Education } & \multicolumn{3}{|c|}{ D. Elementary Education } & & & \\
\hline
\end{tabular}

Table 3 proves that there isn't statistically significant difference between preservice teachers who study at different departments in terms of academic perfectionism and irresponsibility ( $>>05)$. Conversely, there is statistically significant difference between preservice teachers who study at different departments in terms of negative perceptions regarding instructors, academic procrastination and the quality of perceived academic task $(\mathrm{p}<.05)$. According to Scheffe test which is conducted to determine between which groups the differences are seen, the level of academic procrastination and the quality of perceived academic task of teacher candidates who study at Psychological Counseling and Guidance Education are higher than the levels of preservice teachers who study at Elementary Education. Additionally, it is determined that negative perceptions regarding instructors' level of the preservice teachers who study at Elementary Mathematics Education is higher than those who study at Psychological Counseling and Guidance Education and Elementary Education.

Findings that show whether preservice teachers' behaviors of academic procrastination differ in terms of class level 
are given in the Table 4.

Table 4. ANOVA Results That Illustrates the Preservice Teachers' Behaviors of Academic Procrastination in terms of Class Level

\begin{tabular}{|c|c|c|c|c|c|c|c|c|c|c|c|}
\hline Dimensions & $\begin{array}{l}\text { Class } \\
\text { level }\end{array}$ & $\mathrm{n}$ & M & $\mathrm{Sd}$ & $\begin{array}{l}\text { Source of } \\
\text { Variance }\end{array}$ & $\begin{array}{l}\text { Sum of } \\
\text { Squares } \\
\end{array}$ & $\mathrm{df}$ & $\begin{array}{l}\text { Mean } \\
\text { Square }\end{array}$ & $\mathrm{F}$ & $\mathrm{p}$ & Difference \\
\hline \multirow{4}{*}{$\begin{array}{c}\text { Academic } \\
\text { procrastination behavior }\end{array}$} & 1. & 60 & 2.35 & .70 & B. G. & 7.452 & 3 & 2.484 & \multirow{4}{*}{6.345} & \multirow{4}{*}{$.000 *$} & \multirow{4}{*}{$\begin{array}{l}1<3,4 \\
2<3,4\end{array}$} \\
\hline & 2. & 10 & 2.10 & .89 & W. G. & 81.030 & 207 & .391 & & & \\
\hline & 3. & 92 & 2.70 & .54 & & & & & & & \\
\hline & 4. & 49 & 2.69 & .63 & & & & & & & \\
\hline \multirow{4}{*}{ Irresponsibility } & 1. & 60 & 2.34 & .85 & B. G. & 8.142 & 3 & 2.714 & \multirow{4}{*}{4.282} & \multirow{4}{*}{$.006^{*}$} & \multirow{4}{*}{$1<4$} \\
\hline & 2. & 10 & 2.09 & 1.09 & W. G. & 131.196 & 207 & .634 & & & \\
\hline & 3. & 92 & 2.67 & .72 & & & & & & & \\
\hline & 4. & 49 & 2.76 & .81 & & & & & & & \\
\hline \multirow{4}{*}{$\begin{array}{l}\text { Quality of perceived } \\
\text { academic task }\end{array}$} & 1. & 60 & 2.09 & .78 & B. G. & 6.293 & 3 & 2.098 & \multirow{4}{*}{4.262} & \multirow{4}{*}{$.006 *$} & \multirow{4}{*}{$1<3$} \\
\hline & 2. & 10 & 1.90 & .71 & W. G. & 101.872 & 207 & .492 & & & \\
\hline & 3. & 92 & 2.44 & .67 & & & & & & & \\
\hline & 4. & 49 & 2.23 & .66 & & & & & & & \\
\hline \multirow{4}{*}{$\begin{array}{l}\text { Negative perceptions } \\
\text { regarding instructors }\end{array}$} & 1. & 60 & 2.58 & .97 & B. G. & 16.741 & 3 & 5.580 & \multirow{4}{*}{6.771} & \multirow{4}{*}{$.000 *$} & \multirow{4}{*}{$1<3,4$} \\
\hline & 2. & 10 & 2.62 & 1.32 & W.G. & 170.607 & 207 & .824 & & & \\
\hline & 3. & 92 & 3.13 & .76 & & & & & & & \\
\hline & 4. & 49 & 3.26 & .98 & & & & & & & \\
\hline \multirow{4}{*}{ Academic perfectionism } & 1. & 60 & 2.70 & .75 & B. G. & 8.025 & 3 & 2.675 & \multirow{4}{*}{4.168} & \multirow{4}{*}{$.007 *$} & \multirow{4}{*}{$2<1,3,4$} \\
\hline & 2. & 10 & 1.98 & 1.22 & W. G. & 132.856 & 207 & .642 & & & \\
\hline & 3. & 92 & 2.89 & .82 & & & & & & & \\
\hline & 4. & 49 & 2.77 & .82 & & & & & & & \\
\hline
\end{tabular}

$* \mathrm{p}<.05$

For preservice teachers' scores concerning academic procrastination and its sub dimensions according to their class level, there is a statistically significant difference between preservice teachers $(\mathrm{p}<.05)$. According to Tukey test is conducted to determine between which class levels the difference is seen, academic procrastination level of preservice teachers who are in third and fourth grade are higher than procrastination level of preservice teachers who are in first and second grade. Irresponsibility level of preservice teachers who are in fourth grade are higher than irresponsibility level of teacher candidates who are in first grade. It is also determined that preservice teachers who are in third grade exhibits more behaviors related to the quality of perceived academic task when compared with the preservice teachers who are in first grade. Additionally, negative perceptions regarding instructors of preservice teachers who are in third and fourth grade is higher than the ones who are in first grade. Lastly, it is a fact that preservice teachers who are in second grade exhibits more behaviors related to academic perfectionism when compared with the preservice teachers who are in first, third and fourth grade.

\section{Conclusion and Discussion}

As a result of the present study which aims to investigate preservice teachers' academic procrastination behaviors in terms of different variables, it is found that the level of preservice teachers' academic procrastination is quite low. Preservice teachers are not inclined to academic procrastination. In terms of sub dimensions, preservice teachers mostly engage in academic procrastination behaviors in the sub dimension which is called as negative perceptions regarding instructors when it is compared with other sub dimensions. On the other hand, they less often engage in academic procrastination behaviors in the sub dimension which is quality of perceived academic task when it is compared with other sub dimensions. It can be stated that negative perceptions regarding instructors is the most frequent reason for academic procrastination behaviors. Students who don't like their own teacher tend to neglect academic tasks. When the literature is reviewed, it is found that there are different findings obtained by various 
researches. In their studies, Rabin, Fogel and Nutter-Upham (2011), Solomon and Rothblum (1984) and Uzun Özer, Demir and Ferrari (2009) determine that undergraduate students are more inclined to academic procrastination behaviours.

Another results of the research states that the procrastination means are different for gender groups. Male preservice teachers are more likely to procrastinate their academic works. In the literature, there are a lot of different research studies which support these findings (Aydoğan \& Özbay, 2012; Balkıs, 2007; Bulut \& Ocak, 2017; Çelikkaleli \& Akbay, 2013; Özer \& Altun, 2011; Uzun Özer, Demir, \& Ferrari, 2009). In the study which is conducted to investigate the academic procrastination behaviors of high-schoolers who are in fourth grade, Aydoğan and Özbay (2012) state that male teacher candidates engage in more academic procrastination behaviors when compared with female teacher candidates. Balkıs (2007) in a research based on academic procrastination behaviors, find that male teacher candidates perform academic procrastination behavior more frequently and significantly when compared with female teacher candidates. Bulut and Ocak (2017) reveal that when the topic is examined in terms of sub dimensions namely negative perceptions regarding instructors and quality of perceived academic task, male teacher candidates perform academic procrastination behavior significantly more than female teacher candidates. In their study which is conducted on the academic procrastination behaviors of undergraduate students, Çelikkaleli and Akbay (2013) find that male teacher candidates are more likely to procrastinate their own academic tasks. As a result of the study conducted by Özer and Altun (2011) to determine the reasons of academic procrastination behavior, it is found that students procrastinate their work due to the fear of failure and laziness. In their work which aim to reveal the gender differences related to academic procrastination behavior, Uzun Özer, Demir and Ferrari (2009) say that female students are more inclined to delay their own academic tasks. On the other hand, there are different studies which claim that there isn't any difference between the level of academic procrastination behavior in terms of gender (Çakıc1, 2003; Effert \& Ferrari, 1989; Ekşi \& Dilmaç, 2010; Ferrari, 1991; Gülebağlan, 2003; Haycock, McCarty, \& Skay, 1998; Hess, Sherman, \& Goodman, 2000; Johnson \& Bloom, 1995; Kachgal, Hansen, \& Nutter, 2001; Karabıyık Çeri, Çavuşoğlu, \& Gürol, 2015; Onwuegbuzic, 2004; Rothblum, Solomon, \& Murakabi, 1986; Solomon \& Rothblum, 1984; Watson, 2001; Zarick \& Stonebraker, 2009).

According to another important result which is obtained via present research, it is apparent that there is statistically significant difference between preservice teachers who study at different departments in terms of negative perceptions regarding instructors, academic procrastination and the quality of perceived academic task. Also, it is seen that there isn't any significant relationship between irresponsibility, academic perfectionism and department at which students study. Preservice teachers of Psychological Counseling and Guidance Education are more inclined to delay their academic works when they are compared with Elementary Education. Balkis (2007) states that level of academic procrastination behaviors differs according to major of teacher candidates. Students who study at science departments are more inclined to procrastinate their academic responsibilities compared to the students of other departments. Ekşi and Dilmaç (2010) also find that teacher candidates of Psychological Counseling and Guidance Education more frequently delay their academic works when compared with other teacher candidates studying at other departments.

Lastly, it is found that preservice teachers behaviors of academic procrastination and its sub dimensions namely irresponsibility, the quality of perceived academic task, negative perception regarding instructors and academic perfectionism differs in a statistically significant way in terms of class level of the preservice teachers. As a result of the present study, it is stated that academic procrastination level of preservice teachers who are in third and fourth grade are higher than the levels of those who are in first and second grade. For the preservice teachers who are final year students, it can be said that anxiety related to KPSS (a national exam to be appointed as a tenured teacher) and job-seeking anxiety causes the academic procrastination. In the literature on academic procrastination, there are a lot of studies which support this finding such as Balkıs (2007), Bulut and Ocak (2017), Ekşi and Dilmaç (2010), Karabıyık Çeri, Çavuşoğlu and Gürol (2015) and McCown and Roberts (1994). Balkıs (2007) observes that academic procrastination level of teacher candidates who are in second, third and fourth grade is higher than the ones who are in first grade. Bulut and Ocak (2017) determine that quality of perceived academic task level of teacher candidates who are in third and fourth grade is higher than the ones who are in first and second grade with a statistically significant level. According to Ekşi and Dilmaç (2010) students at fourth grade are more inclined to delay their academic tasks compared to other class levels. Similarly, Karabıyık Çeri, Çavuşoğlu and Gürol (2015) show that academic procrastination level of students who are in 4th grade are higher than the ones who are in third grade. McCown and Roberts (1994) assert that tendencies related to academic procrastination of the students who are in third and fourth grade is higher than the ones who are in first and second grade. Conversely, Çelikkaleli and Akbay (2013) claim that final year students less frequently procrastinate their own academic tasks. 
All in all, it is evident that academic procrastination is one of the crucial concepts for students' academic success. The concept itself should be investigated elaborately in terms of its relationships with other concepts such as abseentism, alienation, burnout and academic success. It should be noted that academic procrastination can have a key role in explaining anxiety, demotivation and other personality variables of learners. Future research should focus on uncovering the concept thoroughly both for learner and teacher contexts.

\section{References}

Aydoğan, D., \& Özbay, Y. (2012). Akademik erteleme davranışının benlik saygısı, durumluluk kaygı, öz-yeterlilik açısından açıklanabilirliğinin incelenmesi. Pegem Ĕ̆itim ve Öğretim Dergisi, 2(3), 1-9. https://doi.org/10.14527/C2S3M1

Bacanlı, H., İlhan, T., \& Aslan, S. (2009). Beş faktör kuramına dayalı bir kişilik ölçeğinin geliştirilmesi: Sıfatlara dayalı kişilik testi (SDKT). Türk Eğitim Bilimleri Dergisi, 7(2), 261-279.

Balkıs, M. (2007). Öğretmen adaylarının davranışlarındaki erteleme eğiliminin, karar verme stilleri ile ilişkisi. Pamukkale Üniversitesi Eğitim Fakültesi Dergisi, 21(1), 67-83.

Balkis, M., \& Duru, E. (2007). The evaluation of the major characteristics and aspects of the procrastination in the framework of psychological counseling and guidance. Kuram ve Uygulamada Egitim Bilimleri, 7(1), 376.

Balkıs, M., Duru, E., Buluş, M., \& Duru, S. (2006). Üniversite öğrencilerinde akademik erteleme eğiliminin çeşitli değişkenler açısından incelenmesi. Ege Ĕ̆itim Dergisi, 7(2), 57-73.

Brownlow, S., \& Reasinger, R. D. (2000). Putting off until tomorrow what is better done today: academic procrastination as a function of motivation toward college work. Journal of Social Behavior \& Personality, 15, 15-34.

Bulut, R., \& Ocak, G. (2017). Öğretmen adaylarının akademik erteleme davranışlarını etkileyen etmenler. E-Uluslararası Eğitim Araştırmaları Dergisi, 8(2), 75-90.

Çakıcı, D. Ç. (2003). Lise ve Üniversite Öğrencilerinde Genel Erteleme ve Akademik Erteleme Davranışının İncelenmesi. Yayımlanmamış yüksek lisans tezi, Ankara Üniversitesi, Eğitim Bilimleri Enstitüsü, Ankara.

Çelikkaleli, Ö., \& Akbay, S. E. (2013). Üniversite öğrencilerinin akademik erteleme davranışı, genel yetkinlik inancı ve sorumluluklarının incelenmesi. Ahi Evran Üniversitesi Kırşehir Eğitim Fakültesi Dergisi, 14(2), 237-254.

Deniz, M. E., Traş, Z., \& Aydoğan, D. (2007). Akademik erteleme ve denetim odağının duygusal zeka yeteneklerine göre incelenmesi. IX. Ulusal Psikolojik Danışma ve Rehberlik Kongresi, 17-19.

Effert, B., R., \& Ferrari, J. R. (1989). Decisional procrastination: Examining personality correlates. Journal of Social Behavior \& Personality, 4, 151-156.

Ekşi, H., \& Dilmaç, B. (2010). Üniversite öğrencilerinin genel erteleme, karar vermeyi erteleme ve akademik erteleme düzeylerinin sürekli kaygı açısından incelenmesi. Uludă̆ Üniversitesi Eğitim Fakültesi Dergisi, 23(2), 433-450.

Ferrari, J. R. (1991). Compulsive Procrastination: Some Self-Reported Characteristics. Psychological Reports, 68, 455-458. https://doi.org/10.2466/pr0.1991.68.2.455

Gülebağlan, C. (2003). Öğretmenlerin işleri son ana erteleme eğilimlerinin, mesleki yeterlilik algıları, mesleki deneyimleri ve branşları bakımından karşılaştırılmasına yönelik bir araştırma. Yayınlanmamış yüksek lisans tezi, Ankara Üniversitesi, Eğitim Bilimleri Enstitüsü, Ankara.

Haycock, L. A., McCarthy, P., \& Skay, C. L. (1998). Procrastination in college students: The role of self-efficacy and $\begin{array}{llllll}\text { anxiety. Journal of } \quad \text { Counseling } & \text { Development, } & 76, & 317-324 .\end{array}$ https://doi.org/10.1002/j.1556-6676.1998.tb02548.x

Hess, B., Sherman, Martin F., \& Goodman, M. (2000). Eveningness predicts academic procrastination: The mediating role of neuroticism. Journal of Social Behavior \& Personality, 15(5), 61-75.

Hill, M., Hill, D., Chabot, A., \& Barral, J. (1978). A survey of college faculty and student procrastination. College Students Personal Journal, 12, 256-262.

Johnson, J. L., \& Bloom, A. M. (1995). An analysis of the contribution of the five factors of personality to variance in academic procrastination. Personality and Individual Differences, 18(1), 127-133. https://doi.org/10.1016/0191-8869(94)00109-6 
Kachgal, M. M., Hansen, L. S., \& Nutter, K. J. (2001). Academic procrastination prevention intervention: Strategies and recommendations. Journal of Developmental Education, 25(1), 14-26.

Kağan, M. (2009). Determining the variables which explain the behaviour of academic procrastination in university students. Ankara University, Journal of Faculty of Educational Sciences, 42(2), 113-128.

Karabıyık Çeri, B., Çavuşoğlu, C., \& Gürol, M. (2015). Üniversite öğrencilerinin akademik erteleme düzeylerinin incelenmesi. The Journal of Academic Social Science Studies, 34, 385-394.

Klassen, R. M., Krawchuk, L. L., \& Rajani, S. (2008). Academic procrastination of undergraduates: Low self-efficacy to self-regulate predicts higher levels of procrastination. Contemporary Educational Psychology, 33(4), 915-931. https://doi.org/10.1016/j.cedpsych.2007.07.001

Klassen, R. M., \& Kuzucu, E. (2009). Academic procrastination and motivation of adolescents in Turkey. Educational Psychology, 29(1), 69-81. https://doi.org/10.1080/01443410802478622

Lekich, N. (2006). The relationship between academic motivation, selfesteem, and academic procrastination in college student. Unpublished Masters's Thesis. Truman State University, Kirksville. Missouri, USA.

McCown, W., \& Roberts, R. (1994). A study of academic and work-related dysfunctioning relevant to college version of an indirect measure of impulsive behavior. Integra Technical Papers. Radnot, PA: Integra, Inc.

Ocak, G., \& Bulut, R. (2015). The scale of academic procrastination: Validity and reliability study. International Journal of Social Sciences and Education Research, 1(2), 709-726.

Onwuegbuzie, A. J. (2004). Academic procrastination and statistics anxiety. Assessment \& Evaluation in Higher Education, 29(1), 3-19. https://doi.org/10.1080/0260293042000160384

Özer, A., \& Altun, E. (2011). Üniversite öğrencilerinin akademik erteleme nedenleri. Mehmet Akif Ersoy Üniversitesi Eğitim Fakültesi Dergisi, 21, 45-72.

Rabin, L. A., Fogel, J., \& Nutter-Upham, K. E. (2011). Academic procrastination in college students: The role of self-reported executive function. Journal of Clinical and Experimental Neuropsychology, 33(3), 344-357. https://doi.org/10.1080/13803395.2010.518597

Rothblum, E. D., Solomon, L. J., \& Murakami, J. (1986). Affective, cognitive, and behavioral differences between high and low procrastinators. Journal of Counseling Psychology, 33(3), 387-394. https://doi.org/10.1037/0022-0167.33.4.387

Saddler, C. D., \& Sacks, L. A. (1993). Multidimensional perfectionism and academic procrastination: Relationships with depression in university students. Psychological Reports, 73(3), 863-871. https://doi.org/10.2466/pr0.1993.73.3.863

Sarığlu, A. F. (2011). Öğretmen adaylarının akademik erteleme eğilimi ile mükemmeliyetçilik düzeyleri arasındaki ilişkinin incelenmesi. Yayımlanmamış yüksek lisans tezi, İstanbul Üniversitesi Sosyal Bilimler Enstitüsü.

Senecal, C., Julien, E., \& Guay, F. (2003). Role conflict and academic procrastination: A self-determination perspective. European journal of social psychology, 33(1), 135-145. https://doi.org/10.1002/ejsp.144

Senecal, C., Koestner, R., \& Vallerand, R. J. (1995). Self-regulation and academic procrastination. The Journal of Social Psychology, 135(5), 607-619. https://doi.org/10.1080/00224545.1995.9712234

Solomon, L. J., \& Rothblum, E. D. (1984). Academic procrastination: Frequency and cognitivebehavioral correlates. Journal of Counseling Psychology, 31, 503-509. https://doi.org/10.1037/0022-0167.31.4.503

Steel, P. (2007). The nature of procrastination: A meta-analytic and theoretical review of quintessential self-regulatory failure. Psychological bulletin, 133(1), 65. https://doi.org/10.1037/0033-2909.133.1.65

Uzun Özer, B., Demir, A., \& Ferrari, J. R. (2009). Exploring academic procrastination among Turkish students: Possible gender differences in prevalence and reasons. The Journal of Social Psychology, 149(2), 241-257. https://doi.org/10.3200/SOCP.149.2.241-257

Uzun Özer, B. (2005). Academic procrastination: Prevalence, self-reported reasons, gender difference and it's relation with academic achievement. Unpublished Master Thesis. Middle East Technical University, Ankara, Turkey.

Watson, D. C. (2001). Procrastination and the five-factors model: A facet level analysis. Personality and Individual Differences, 30, 149-158. https://doi.org/10.1016/S0191-8869(00)00019-2 
Zarick, L. M., \& Stonebraker, R. (2009). I'll do it tomorrow: the logic of procrastination. College Teaching, 57(4), 211-215. https://doi.org/10.3200/CTCH.57.4.211-215 